\title{
The Examination of the Corporate Governance System at Supplier Companies: Empirical Evi- dence from Hungarian Automotive Industry
}

\author{
- Ercsey Ida
}

\begin{abstract}
Information management and the organizational structure can contribute to the firms' competitive advantage and business success. In the first part of our study we summarize the results we obtained by analyzing the corporate governance system in connection with the structure of enterprises and their decision making. Then we have an insight into the leadership style of the suppliers from the point of view of the participation of the staff in decision making. In the second part we analyze the information management of the supplier companies on the basis of the answers from the management. We evaluate the strategic and the operational concept of information management, proceeding from the strategy-making activity. The accomplishment of permanent renewal and willingness to innovate are both indispensable for achieving elasticity in organizations. We explore how the suppliers introduce innovation in connection with the firm structure and the information system. Finally, we consider how some essential company characteristics, namely company size, ownership, region, and the width of the product assortment, affect various company functions.
\end{abstract}

Keywords: competitive advantage, corporate governance, decision making, information management, innovation JEL Classification: M10, M15

\section{INTRODUCTION}

The topicality of the research theme is proved by the fact that in Hungary (between 1992 and 2001) the production of road vehicles increased 37-fold and the manufacturing of vehicle bodywork and trailers increased 40-fold, while the production of road vehicle parts increased 19-fold (Czakó, Gáspár, Jenei, Martits, Németh, Pintér, \& Szántó, 2003). Nowadays the performance of the industry is worth 3000 billion HUF, and we have been able to witness significant fluctuations in production, as well as a $20 \%$ decrease. Output expanded in each of the subsectors in 2014; among them vehicle production was the primary engine of growth: the production of this subsector, which provides more than a quarter of the country's manufacturing output, increased by $21 \%$. The automotive industry has a significant role in the Hungarian economy, illustrated by its added value, which is $10 \%$ of the Hungarian GDP, and the number of employees, which is more than 115 thousand.

Previous pieces of research confirm that the drawing up of corporate strategy, leadership style, and the competitive position of the enterprise have a serious effect on the installation and development of an integrated corporate governance information system. Especially the enterprises in the Hungarian SME sector do not put enough emphasis on questions regarding organizational 
development. When an organization goes through constant changes, strategic flexibility is a critical factor. In an atmosphere of keen competition those enterprises which have a good ability to adapt will survive (Evans, 1991). IT may help the enterprise if the decision maker recognizes those situations in which the enterprise is able to react properly with its applied information technology or if it is able to install the appropriate information system in time.

Our research topic is connected with competitiveness via several dimensions: organizational structure, decision making, innovation, leadership style, and information management.

In the study we first evaluate the decision making of supplier companies from the viewpoint of quickness, and then we examine organizational changes affecting corporate governance. In the second part of our study we gain an insight into the leadership style of supplier companies from the point of view of the participation of the staff in decision making. We put special emphasis on the analysis of information management, which indicates the development of the IT function. We evaluate the strategic and the operational concepts of information management proceeding from the strategy-making activity. The accomplishment of permanent renewal and willingness to innovate are both indispensable for achieving elasticity in organizations. In connection with this we explored the extent to which supplier companies apply complementary innovations related to the organization and the IT system.

\section{LITERATURE REVIEW}

Taking into consideration the global evolution of automotive suppliers, it can be said that the role of Asia (where average annual growth is 14.9\%) and Eastern Europe (where average annual growth is $12.7 \%$ ) has grown significantly, while production has decreased in the countries of Western Europe (a 3.1\% decrease) and North America (a 1.7\% decrease). Besides these, in South America only a small increase $(2.5 \%)$ could be seen (Lepsényi, 2010). It is widely known that nowadays the technical details of vehicles are so complex that companies manufacturing under their own names (so-called OEM) are not able to cover the entire component manufacturing process. The tendency is shown well by the fact that in 2002 almost half of the finished cars were not manufactured by the primary manufacturer but by the supplier chain (Gelei \& Nagy, 2004). European and Asian vehicle manufacturers built parts manufacturing and assembly capacities in the countries of Eastern Central Europe to exploit the competitive advantages that can be found in the region. Requirements for suppliers have become more and more complex: global participation, high quality, and accuracy in delivery, price, and productivity, as well as technical innovation. The reasons for manufacturing in Eastern Central Europe are the highly skilled labour, knowledge and experience of the automotive industry, employee loyalty and education, the presence of small- and medium-sized enterprises, and compliance with material prices and the terms of contracts. The low level of R\&D activity can be mentioned as a shortcoming of the industry, but mostly not among large companies but among small and medium-sized ones. Large companies have expanded not only their manufacturing but their development too, while this is not a characteristic of medium-sized suppliers. The quality of $\mathrm{R} \& \mathrm{D}$ activity is vital from the point of view of suppliers' successfulness (Rechnitzer \& Smaho, 2012). 
More approaches to the definition of corporate governance system are known in the literature. A synonym for an integrated corporate governance system is ERP (Enterprise Resource Planning), which means the resource planning of the enterprise. According to the definition of Wallace and Kremzar (2006), an ERP system forecasts and harmonizes demand and transport. With its help customers and suppliers can be linked to one complete supply chain, appropriate methods can be used in decision making, and sales, marketing, production units, logistics, purchase, finance, product development, and human resources can be harmonized (Wallace \& Kremzar, 2006). According to a different approach, the definition of an integrated corporate governance system refers to management activity in a broader sense and to software in a narrower sense. In our study we use the broader sense because it is an enterprise-wide system, the central element of which is modern information technology, but its installation requires the re-planning of corporate processes and the qualitative modification of the enterprise's governance. Business planning governs the organization and its operation, technology planning process identifies opportunities, which may affect business strategy through strategic planning. Several authors (Porter \& Millar, 1985; Wilson, Avison, Jones, \& Powell, 2004) created models for the harmonization of information strategy and business strategy together with their practical applicability. Croteau and Bergeron (2001) examine with which IT planning and management background the best performance can be reached in case of different business strategies. Nowadays, IT is highly embedded within enterprises, thus real advantage is provided by the development of information systems (IS) competencies as well as the bounding together of resources, which is hard to copy (Peppard \& Ward, 2004). There are several theoretical models that explain user acceptance of information systems (Leem \& Kim, 2004; Weill \& Olson, 1989). The technology acceptance model (TAM) is applied IS model to explore end user adoption of IT. TAM proposes the perceived usefulness and perceived ease of use the given information system (Venkatesh \& Bala, 2008). According to Sun, Bhattacherjee and Ma (2009) the examination of IT usage is important for recognition the criteria is correlated with usage e.g. performance, quality of decision making.

When researchers started to show interest in ERP discussed the functionality of ERP system and the complexity of implementation (Seddon, Calvert, \& Yang, 2010; Swan, Newell, \& Robertson, 1999). Van Everdingen, Hillegersberg and Waarts (2000) surveyed more than 2000 European companies in order to study adoption of ERP in different industries. The early researches focused on implementation issues and the use of best practices in organisational processes. The companies worked as an organisational structure which had separated the functional fields therefore each department is completely isolated from other ones. ERP integrates all business functions into a system with a shared database. This system provides some advantages for companies to improve the performance of the organization, the quality of information but it does not decrease the costs of information technology (Shang \& Seddon, 2002). Shang \& Seddon highlighted five dimensions to benefits of this system namely, operational, managerial, strategic, IT infrastructure and organizational one. Besides, a large body of research has identified critical factors for successful implementation of ERP system. Some of them found that these benefits can vary across industries and depend on the implementing firms (Davenport, 2000). The implementation of this system can create the initial conditions and the foundation of technology for integration (Lee, Lee, Olson, \& Chung, 2010; Nwankpa, 2015). Schwarz \& Chin (2007) and Nwankpa and Roumani (2014) have found that system usage is a critical predictor for success of system 
implementation (Karimi, Somers, \& Battacherjee, 2007). Previous studies explored the factors of system usage, namely managerial commitment, social factors, compatibility which influence positively the ERP system usage. Nwankpa (2015) investigated the organizational factors such as technical resources, organizational fit, extent of ERP implementation that are drivers of system usage (Chang, Cheung, Cheng, \& Yeung, 2008; Kallunki, Laitinen, \& Silvola, 2011). According to the literature (Helo, 2004; Verdu \& Gomez-Gras, 2009; Zajac, Kraatz, \& Bresser, 2000) the managerial flexibility is particularly important for organizations operating in a volatile market or in a new technologies. Researchers recognized the elements of managerial flexibility, time and cost. Besides, there are additional ones, variety aspect belonging to the managers' ability to develop alternative methods, and intention element for proactive behaviour. In order to achieve high-quality business solutions and reach greater innovative performance firms apply knowledge integration mechanisms ('Tsai \& Hsu, 2014; Teo \& Bhattacherjee, 2014).

When dealing with the operation of enterprises elasticity often comes up as a source of competitive advantage. However, the different pieces of research found different results regarding the correlations between elasticity and IT systems. IT systems mean a precisely-planned stable process; therefore they are able to handle only such special events for which the system is prepared. The enterprise may preserve its ability to quickly react to environmental changes with elastic IT after the installation of stable IT procedures.

\section{DATA COLLECTION AND METHODOLOGY}

This paper is a part of a large research and our objective to know the governance system of suppliers in automotive industry. The corporate governance system is a complex concept and it can be analysed on strategic and operative levels. The research questions in connection with our research topic are following:

Q1: What is the relationship among the decision-making of suppliers, the organisational structure and the size of company?

Q2: How significant is the decision-making in suppliers in the maintenance of the competitiveness?

Q3. What is connection between the corporate strategy of suppliers and the approach related to information management?

Q4. How the level of innovation is related to the organisation and IT development?

Q5: What are the main features of two Hungarian Regions related to corporate structure and decision making in suppliers?

The basis for the analysis of primary research is a survey conducted in 2011 among automotive supplier companies. Data Collection Institute commissioned by SZE Research Group for Spatial Economics and Automotive Industry collected data in June by means of a questionnaire. Besides basic data, data were collected linked to nine topic areas. In the present study we introduce the analysis of one topic area, namely corporate governance activity among automotive supplier companies. As a result of the questionnaire survey, data were collected from 118 companies from the whole country (Ercsey, 2012). 
The regional distribution of the respondent companies shows that more than one fourth of the respondent companies operate in the Central-Hungarian region (12 of them in Budapest), whereas the rate of companies is lower than ten percent in two regions (Northern Great Plain region and South-Transdanubia Region). The majority of the companies $(60.2 \%)$ were set up between 1990 and 2000 and they usually have only one premise (80.5\%). A significant part of the companies ( $88 \%$ ) were set up by a kind of mechanic, in case of 53 companies the founder was domestic individual, whereas in case of 32 companies that was foreign company. In case of the distribution of the companies based on the size of the company (based on the number of employees) it can be stated that $3.4 \%$ of the suppliers of automotive industry are micro-sized enterprises, $70.1 \%$ of them are small- and medium-sized enterprises, the rate of large companies is almost one fourth, which significantly exceeds the rate of Hungarian large companies. Based on the annual turnover (in 2010), the rate of micro-sized enterprises is more than one third. The majority of the respondent companies (89\%) operate in the form of Ltd. The followings characterise the distribution of companies based on the nature of the settlement: 12 companies operate in Budapest, 42 operate in town with county rights, 46 in other towns and 18 in municipalities. This means that $87.7 \%$ of the respondent suppliers operate in towns.

During the analysis of the data we counted descriptive statistics (frequency, mean, standard deviation) to the scale type, but besides these to explore deeper correlations we applied bivariate methods (cross-table analysis, variance analysis). In case of cross-table analysis we checked the condition of the Chi2 test, the meet of cell frequency requirements. According to the more stringent condition, cross-table analysis cannot be considered reliable until the expected value of each cell reaches 5 (Malhotra, 2009). From the viewpoint of the applicability of variance analysis we examined the realisation of the condition of homogeneity of dispersion with Levene-test. So dependent variable has the same dispersion in case of different levels of independent variable.

We analysed the corporate governance activity of supplier companies with the help of five variables. We used three company-demographical factors (company size, owner's identity, and region) and two corporate characteristics (the width of product range) for the deeper analysis of variables.

\section{RESULTS}

First we explore the decision-making of supplier companies from the viewpoint of quickness, and then we investigate the organisational changes affecting corporate governance. After this we get an insight into the leadership style of supplier companies from the point of view of the participation of the staff in decision-making. Besides, we recognize the role of information management at supplier companies.

\subsection{Decision-making in the organisation of supplier companies}

The organizational structure can be described on the bases of different variables such as centralization, formalization and complexity. Centralization reflects the hierarchical nature of organizations and the degree of dependence of supervisors in decision-making about individually-assigned tasks (Cabello, Camacho, \& Vázquez, 2012). 
The effective corporate governance is characterized by the decomposition of decision-making process and matching the steps of this process to managers and owners (Pavel, Stanislav, Petr, \& Pavel, 2012).

From the viewpoint of corporate governance it is a basic question to what extent the companies' organisational structure and its change support decision-making. If the number of hierarchylevels is high in the company, it may impede control, direct communication and the elastic of the company as well. In surveys conducted among SMEs, respondents mentioned the followings as the most typical characteristics: the ability to work tightly with suppliers and customers as well as the features related to elasticity (adaptation to customer needs, quick decisions in the given organisational structure) (Fodor, 2005).

In our empirical research we asked the respondents to evaluate in a 5-point scale (1: not typical at all, 5: fully typical) to what extent the statement characterises the company they manage. Based on the most typical view of leaders "In the less hierarchical structure of the organisation the informationflow is fast, accordingly we can decide rapidly" (mean: 3.78). We examine what peculiarities are typical among companies having different company-demography (company size, owner's identity, and region) with regard to organisational structure and IT advancement. In case of the hierarchical organisational structure feature, company size (based on the number of employees) significantly affects the findings. As we expected, the representatives of micro- and small-enterprises evaluated this feature higher than the mean (Tab. 1).

Tab. 1 - The quickness of decision-making in organisation of suppliers. Source: own

\begin{tabular}{|l|c|c|}
\hline Size of the firm & $\begin{array}{c}\text { Quickness of decision- } \\
\text { making Mean (1-5) }\end{array}$ & $\begin{array}{c}\text { Standard } \\
\text { deviation }\end{array}$ \\
\hline Micro-enterprise & 4.67 & 0.577 \\
\hline Small-enterprise & 4.28 & 0.934 \\
\hline Medium-enterprise & 3.46 & 1.164 \\
\hline Large enterprise & 3.39 & 1.066 \\
\hline Total & 3.78 & 1.122 \\
\hline
\end{tabular}

Note: ANOVA results, F=6.472; Sig. $=0.000 ;$ Levene-test sig. $=0.147 ;$ Eta2 $=14.9 \%$

Companies' ownership background gave two distinct feature levels. In case of domestic companies according to the view of fully Hungarian private individuals (4.25) and Hungarian enterprises (4.20), the statement regarding the less hierarchical organisational structure is more typical than in case of fully foreign enterprises (3.28), foreign private individuals (3.10), and foreign financial investors (2.00).

Since the survey completely covered domestic automotive supplier companies territorially, we also wanted to know if there is a significant difference in the evaluation of companies belonging to different regions. We received relatively slight differences. Quick decisions related to less hierarchical organisational structures characterise the companies from the regions of Northern Hungary (mean: 4.25) and Central Hungary (mean: 3.88). However, supplier companies of the Western Transdanubia Region (mean: 3.69) are less characterised by the statement regarding hierarchical organisational structure compared to the sample mean. 
With regard to the competitiveness of supplier companies, we asked several internal factors in the questionnaire. We looked for an answer to what extent the quickness of decision-making plays an important role from the viewpoint of the maintenance of supplier companies' competitiveness. If the management does its duties effectively based on the available information, it enhances the responsively of the enterprise. Figure 1 illustrates that the smaller the supplier company is, the more important quickness is in decision-making. ANOVA result shows it is not significant differences among average values of company' groups but it can be seen the tendency in managers' opinions.

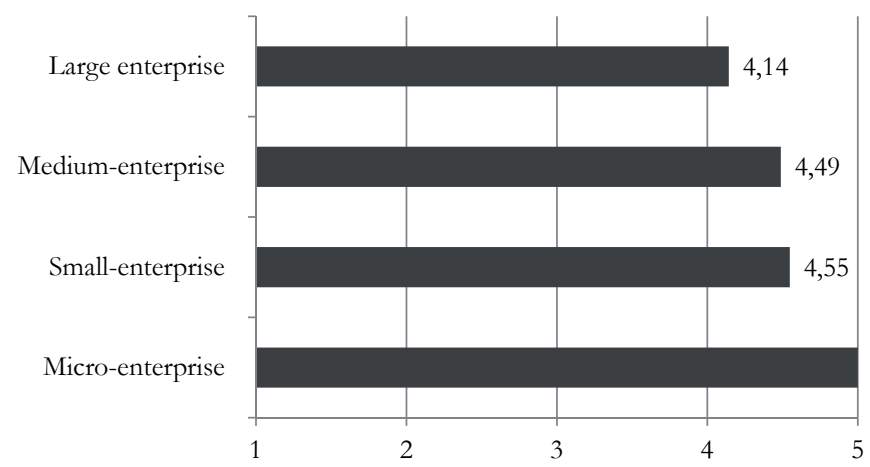

Fig. 1 - Importance of quickness of decision-making in the maintenance of the company's competitiveness (1-5).

Source: own compilation

A new product, a new or a further-developed technological process would not give the expected results alone if it weren't for other innovative activities linked to it. Organisational innovation means the introduction of new methods of corporate governance and work organisation. According to a KSH (2011) survey, among automotive companies of Western Transdanubia Region every third applied such methods between 2006 and 2008 to improve their market positions. One fourth of them introduced new business practice and with similar frequency they took over or developed new methods of work organisation and decision-making. In our survey we collected information regarding what complementary innovation related to the organisation was achieved by supplier companies in the last three years. Large and micro-enterprises hold the first place in introducing new methods of work organisation and work management. Mediumenterprises and large ones used several sources to change organisational structure. In view of the findings, the introduction of new methods for decision-making was de-emphasised; perhaps companies showed little interest in this field. Figure 2 illustrates those complementary innovations which were linked to the suppliers' organisation in the past three years. 
$\square$ Introduction of new method for work control, organization

- Change in the organization structure

Introduction of new method for decision making

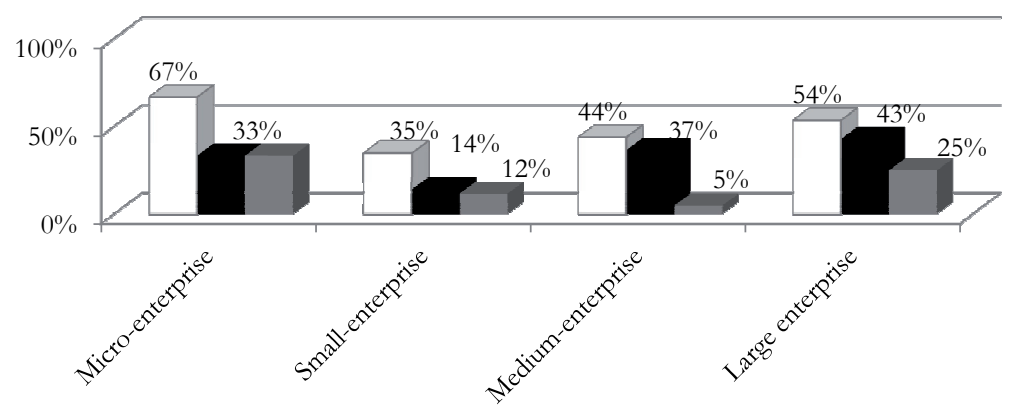

Fig. 2 - Innovation rate related to the organisation based on company size

Source: own compilation

Note: Crosstable result: $C_{b i}{ }^{2}=4.606$, Sig. $=0.012$. Cramers' $V$ coeff. $=0.261$

A priority issue of corporate governance is to what extent the organisational structure of supplier companies adjust to the challenges of external environment; and to what extent the management takes internal abilities into consideration when designing and changing structure. Next, we wanted to know to what extent the change in organisational structure made corporate governance more difficult in the past years. Based on the mean (2.28), we can say that it wasn't a characteristic of the supplier companies of our sample. The extent of corporate governance difficulties resulting from the change in organisational structure is very low, and it rather affected large enterprises (mean: 2.54) (Table 2). ANOVA result shows it is not significant differences among average values of company' groups but it can be seen the tendency in managers' opinions.

Tab. 2 - The level of difficulties to corporate governance system Source: own compilation

\begin{tabular}{|l|c|c|}
\hline Company size & $\begin{array}{c}\text { Difficulties to corporate } \\
\text { governance system Mean } \\
(1-5)\end{array}$ & $\begin{array}{c}\text { Standard } \\
\text { deviation }\end{array}$ \\
\hline Micro-enterprise & 2.00 & $\mathrm{x}$ \\
\hline Small-enterprise & 2.02 & 1.297 \\
\hline Medium-enterprise & 2.37 & 1.392 \\
\hline Large enterprise & 2.54 & 1.319 \\
\hline Total & 2.28 & 1.337 \\
\hline
\end{tabular}

Based on the comparison by regions we can state that mostly the leaders of enterprises from Western Transdanubia Region experienced difficulties in corporate governance due to organisational changes in the past years. Besides them, the enterprises of Central Hungary Region expe- 
rienced more difficulties in this field than the average. Figure 3 shows difficulties in corporate governance due to the change of organisational structure by region.

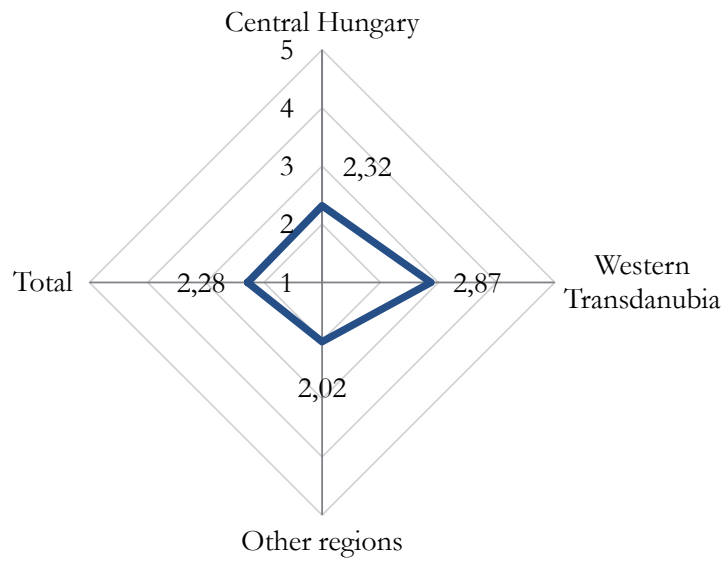

Fig. 3 - The level of difficulties to corporate governance system (1-5) Source: own compilation

\subsection{The analysis of leadership style among supplier companies}

Belás (2013) found that style of leadership in a company is an important element for the growth of competitiveness and business performance.

With the next question in relation to the leadership style we examined to what extent participative leadership, which includes consultation with staff and the consideration of their recommendations in decision-making, is a characteristic of supplier companies. Supposedly, the same leader is able to use more styles depending on the personal characteristics of the employee and on environmental factors (e.g. the structuredness of the task). Based on the findings of the domestic survey among SMEs, it can be seen that company representatives considered the involvement of staff in decision-making less typical (Fodor, 2005). Based on the results of our survey, it can be seen that respondents considered the involvement of staff in decision-making less characteristic (mean: 3.12). Table 3 shows the mean and the standard deviation of the analysed variables. The involvement of staff in decision-making doesn't appear markedly in the leadership style of supplier companies, and we found higher values than the sample mean (3.15) among micro-enterprises (with a fairly large standard deviation) and medium ones (Table 3).

Tab. 3 - The level of staff participates in decision-making. Source: own compilation

\begin{tabular}{|l|c|c|}
\hline Company size & $\begin{array}{l}\text { Level of staff participates in } \\
\text { decision-making Mean (1-5) }\end{array}$ & $\begin{array}{c}\text { Standard } \\
\text { deviation }\end{array}$ \\
\hline Micro-enterprise & 3.33 & 1.528 \\
\hline Small-enterprise & 3.00 & 1.175 \\
\hline
\end{tabular}




\begin{tabular}{|l|c|c|}
\hline Medium-enterprise & 3.29 & 1.230 \\
\hline Large enterprise & 3.14 & 1.008 \\
\hline Total & 3.15 & 1.157 \\
\hline
\end{tabular}

ANOVA result shows there are not significant differences among average values of firm' groups.

The ownership background of supplier companies divided the views of enterprises in the sample regarding leadership style. Regarding foreign enterprises, the involvement of staff in decisionmaking is more typical in case of partly foreign-owned enterprises (4.00) than in case of fully foreign-owned enterprises (3.13), foreign private individuals (3.30) and foreign financial investors (3.00). Besides, it is rather typical for the leaders of fully Hungarian-owned enterprises (mean: 3.80) to consider the recommendations of employees in decision-making.

\subsection{The analysis of questions related to the information management of supplier companies}

From the viewpoint of corporate governance and decision-making the IT advancement of enterprises is an important question. Due to the traditionally supporting characteristic of IT function, operative-level application reached higher values (mean: 3.59) than strategic approach. On the other hand, the importance of information management is indicated by the fact that almost half of the respondent enterprises (46\%) consider IT strategy necessary for responding to marketenvironmental challenges (mean: 3.28).

These findings confirm the general tendency. Approximately one third of Hungarian companies make written IT strategy either as part of the corporate strategy or in the form of a single document. No improvement was experienced regarding the business-related use of IT (e.g. applications providing competitive advantage) compared to previous surveys (1999). The research analysing value-creating processes proved that the use of planning and decision-supporting systems strongly correlated with the willingness to a detailed strategic planning (Demeter and Matyusz, 2006). The findings of our empirical research also draw the attention to strategic approach. Half of the enterprises of the sample have a complete strategy, and almost one fourth of them create strategy for some corporate functional fields. Based on the means of Table 4, we can state that the approach related to information management of those enterprises that have written strategy is more favourable.

Tab. 4 - The relationship between the approaches related to information management and corporate strategy. Source: own compilation

\begin{tabular}{|l|c|c|}
\hline Corporate strategy & $\begin{array}{c}\text { Number of } \\
\text { suppliers }\end{array}$ & $\begin{array}{c}\text { Strategic approaches related to } \\
\text { information management } \\
\text { Mean (1-5) }\end{array}$ \\
\hline $\begin{array}{l}\text { Company does not have } \\
\text { a written strategy }\end{array}$ & 25 & 3.00 \\
\hline $\begin{array}{l}\text { Company has an unwritten } \\
\text { strategy }\end{array}$ & 14 & 2.71 \\
\hline
\end{tabular}




\begin{tabular}{|l|c|c|}
\hline $\begin{array}{l}\text { Company has something for } \\
\text { some functional fields }\end{array}$ & 31 & 3.42 \\
\hline $\begin{array}{l}\text { Company has a complete } \\
\text { strategy }\end{array}$ & 45 & 3.51 \\
\hline Total & 115 & 3.28 \\
\hline
\end{tabular}

This century innovations are regarded as a fundamental element of companies' competitiveness (Hájek, Grebenicek, \& Novosák, 2012). To ensure the flexibility of enterprises the following requirements are indispensable: quick and effective information-flow, IT infrastructure appropriate to the current technical level as well as the applications based on this and the leadership processes operating these. In our survey we collected information with regard to what innovation related to IT development was realised by supplier companies in the past three years. Similar to the complementary innovations related to the organisation of supplier companies, large and micro-enterprises hold the first place in this field. Based on the findings, small-enterprises "lagged behind" from the viewpoint of adapting new IT solutions. The reasons for this on the one hand are financial and funding issues, and on the other hand company size which determines and affects the exploitation of opportunities inherent in development. Table 5 shows IT innovations based on company size.

Tab. 5 - Innovation realisation related to IT development based on company size. Source: own compilation

\begin{tabular}{|l|c|}
\hline Company size & $\begin{array}{c}\text { Innovation realisation related } \\
\text { to IT development Frequency } \\
(\%)\end{array}$ \\
\hline Micro-enterprise & $67 \%$ \\
\hline Small-enterprise & $37 \%$ \\
\hline Medium-enterprise & $51 \%$ \\
\hline Large enterprise & $71 \%$ \\
\hline Total & $51 \%$ \\
\hline
\end{tabular}

We also examined what peculiarities characterise enterprises having different company-demography (company size, owner's identity, and region) and width of product range with regard to IT advancement. Among supplier companies we received an extremely high mean in case of microenterprises (4.67). Besides this, the operative-level supporting role of IT is slightly higher than the sample mean in case of large enterprises.

Based on the ownership background of supplier companies, we received different views ranging from medium to very typical with regard to the operative supporting role of IT. It is more typical for Hungarian-owned supplier companies to have an IT function doing operative-level support than for foreign-owned companies.

Information management strategy plays an important role in corporate planning, in exploiting new business opportunities, and in elaborating, applying and controlling competitive strategies. In contrast to our expectations, among supplier companies we received a high mean in case of 
micro-enterprises (4.00), although the number of these enterprises is very low in the sample. Besides this, large enterprises (3.54) focus more strongly on the strategic use of IT than those who mainly consider the technical and organisational aspects of IT among their aims.

Based on the ownership background of supplier companies, we received different views ranging from medium to very typical with regard to the strategic approach of IT. It is more typical for foreign-owned supplier companies to consider information management necessary for responding to market-environmental challenges than for Hungarian-owned companies.

Based on regional comparison, it can be seen that mainly the enterprises of Central Transdanubia Region consider information management necessary to be able to react to market-environmental changes (mean: 3.56). In the meantime, the supplier companies of Southern Transdanubia Region emphasise the operative supporting role of IT (mean: 4.29). The enterprises of Western Transdanubia Region evaluated both strategic approach (mean: 3.50) and operative supporting function (mean: 3.88) higher than the sample mean.

The width of the product range of the supplier company as well as the depth of it may affect the increase of the complexity of corporate processes, which results an increase in the importance of IT issues in corporate strategy. Based on the findings of the survey, we can say that the strategic approach of corporate IT is mainly a characteristic of enterprises having more product lines (at least 11 product lines). However, the operative supporting role of IT function doesn't show significant differences between supplier companies having a few product lines and those having several product lines.

\section{DISCUSSION, IMPLICATIONS AND FURTHER RESEARCH}

This study provides valuable insight into the corporate governance system of automotive suppliers. Our findings indicate there is relationship between the quickness of decision-making and the level of hierarchy in the corporate organisation. These results are consistent with prior examination have conducted among firms in several industries (Fodor, 2005). Previous studies attempted to understand the drivers of governance systems, enterprise resource planning. We have explored some important factors of those drivers, namely improving the decision-making capability in case of the managerial-tactical driver. Further, the performance of information system, e.g. information speed, quality and availability can contribute to the success of operational benefits. Our results reflect some recent research within the literature (Shang \& Seddon, 2002). Contrary to the approaches of companies in developed countries, innovation for decisionmaking was not applied, the suppliers concentrated more resources on the introduction of new methods for work organisation and work management and on the changing of corporate structure. Similarly to previous research findings, we recognized relationship between the approach related to information management and the written strategy. A holistic corporate governance system is very complex, integrating the internal and external management information across an entire organization.

The findings of our study should be practical importance to managers. Present paper tries to identify the importance of information flow, and direct connection among the quality of information system and decision-making, and changes in the organizational structure. Organizations 
should understand and identify factors, namely organizational, technological and individual ones when a complex, integrated information system is implemented in the company. We have to criticize the suppliers' attitude to innovation related to organization. The managers and executives should have the goal to support the effective integration of IT and to harmonize it with the organizational structure. Given the rapid rate of change in IT and the challenges of business practices the companies should investment more effort in organizational innovation.

This study has some limitations. First, our research emphasized a limited number of variables that may influence on the corporate governance system. While these factors play a critical role in influencing of decision-making, information management and indirectly the competitiveness, other factors such as human and financial resources and information system usage may impact the governance system in the organization. Second, the sample size is relative small. Third, the present study is cross-sectional survey from managers. Finally, the respondents' opinions about some factors might vary at different stages of organizational hierarchy. Further research should conduct with larger sample and take a longitudinal approach. Future research could reveal the interrelationships among the organizational, the technological, and the individual variables.

\section{CONCLUSIONS}

The study analyzes the corporate governance activity of automotive supplier companies. First, we summarize the most important findings of the empirical research with regard to the corporate governance issues that were examined, and then we introduce the peculiarities of automotive supplier companies from two highlighted regions.

Q1: What is the relationship between the decision making of suppliers and the organizational structure and the size of company?

In accordance with the general tendencies, the leaders of smaller supplier companies make quicker decisions because of the less hierarchical corporate organization.

Q2: How significant is the decision making in suppliers in the maintenance of competitiveness?

On the evidence of our findings, it can be stated that the smaller the supplier company is, the more important quickness is in decision making.

Q3. What is the connection between the corporate strategy of suppliers and the approach related to information management?

Because of the traditionally supporting role of the IT function, operational-level application received higher value than the strategic approach. Similarly to previous research findings, we can state that the approach related to the information management of those enterprises that have a written strategy is more favourable.

Large enterprises focus more strongly on the strategic use of IT than those smaller supplier companies that mainly consider its technical and organizational aspects among their aims.

Q4. How is the level of innovation related to the organization and IT development?

In view of complementary innovations related to the organization, it can be seen that the in- 
troduction of new methods for decision making was de-emphasized; the supplier companies concentrated more resources on the introduction of new methods for work organization and work management and on the changing of their corporate structure.

Similarly to complementary innovations related to supplier companies' organizations, large and micro-enterprises occupy first place in adapting new IT solutions.

Q5: What are the main features of two Hungarian regions related to corporate structure and decision making in suppliers?

On the basis of a regional comparison, we found the following peculiarities with regard to automotive supplier companies:

Western Transdanubia Region:

- quick decision making related to a hierarchical organizational structure is less typical of the supplier companies in this region compared to the sample mean;

- we can state that mostly the leaders of this region's companies experienced difficulties resulting from the organizational changes in corporate governance in the past years;

- the enterprises in this region gave an evaluation higher than the sample mean with regard to both their strategic approach and operative supporting role.

Central Hungary Region:

- quick decision making related to a less hierarchical organizational structure characterizes the supplier companies in this region compared to the other regions;

- on the basis of the findings, it can be stated that the region's companies experienced more difficulties in corporate governance resulting from organizational changes in the past years than the sample mean;

- The enterprises in this region gave an evaluation appropriate to the sample mean with regard to both their strategic approach and operative supporting role.

Because of the complex nature of organizational governance systems, the information system, the organizational structure, the innovation, or the leadership style alone do not guarantee "best practice" in a company.

\section{Acknowledgement}

The research was funded by the following EU project: „TÁMOP-4.2.1/B-09/1/KONV-2010-0003: Mobility and environment: Automotive Industry, energy and environmental pieces of research in the Middle- and Western-Transdanubia Region. The project is supported by the State of Hungary and the European Union and co-funded by European Social Fund."

\section{References}

1. Belás, J. (2013). The Leadership Style and the Productiveness of Employees in the Banking Sector in Slovakia. Journal of Competitiveness. 5(1), 39-52. doi: 10.7441/joc. 2013.01.03.

2. Cabello, T. C., Camacho, M. Á. R., \& Vázquez, M. V. (2012). The relationship between organizational structure and market orientation. An empirical approach. The International Journal of Management Science and Information Technology. 50-77. http://hdl.handle. net/10419/97889 
3. Chang, M. K., Cheung, W., Cheng, C. H., \& Yeung, J. H. Y. (2008). Understanding ERP system adoption from the user's perspective. International Journal of production economics, 113(2), 928-942. doi:10.1016/j.ijpe.2007.08.011

4. Croteau, A. M., \& Bergeron, F. (2001). An information technology trilogy: business strategy, technological deployment and organizational performance. Journal of Strategic Information Systems. 10(2), 77-99. doi:10.1016/S0963-8687(01)00044-0

5. Czakó, E., Gáspár, J., Jenei, I., Martits, G., Németh, A., Pintér, A., \& Szántó, R. (2003). Magyarország autóiparának helyzetérôl az Európai Unióhoz való csatlakozást megelőzően - a csatlakozás okán várható változások (Situation of automotive industry of Hungary prior to accession to EU), 30. sz. Múhelytanulmány, Budapesti Közgazdaságtudományi és Államigazgatási Egyetem, Budapest

6. Davenport, T. H. (2000). The Future of Enterprise System-Enabled Organizations. Information Systems Frontiers. 2(2), 163-180. doi: 10.1023/A:1026591822284

7. Demeter, K., \& Matyusz, Zs. (2006). Értékteremtés funkcionális alapokon, Az Értékteremtés projekt zárótanulmánya, Versenyben a világgal 2004-2006. (Value creation on functional basis. The final study of Value creation project. Competing with the world 2004-2006.). Budapest: BCE Versenyképesség Kutató Központ.

8. Ercsey, I. (2012). A beszállító vállalatok vállalatirányítási rendszerének elemzése. [The Analysis of the Enterprise Governance System at the Supplier Companies], In: Rechnitzer J, Smahó M (szerk.) A jármúipari beszállítói hálózat Kelet- Közép Európában és Magyarországon. 307 p. Győr: Universitas-Győr Nonprofit Kft., 2012. 132-145.

9. Evans, J. S. (1991). Strategic Flexibility for High Technology Manoeuvres: A Conceptual Framework, Journal of Management Studies, 28 (1), 5-11. doi/10.1111/j.1467-6486.1991.tb00271. $\mathrm{x} / \mathrm{pdf}$

10. Van Everdingen, Y., van Hillegersberg, J., \& Waarts, E. (2000). Enterprise resource planning: ERP adoption by European midsize companies. Communications of the ACM, 43 (4): 27-31. doi: 10.1145/332051.332064

11. Fodor, Z. (2005). Logisztikai információs rendszerek alkalmazásának hatása a kis-és középvállalkozások versenyképességére (The effect of applying logistics information systems on the competitiveness of SMEs). (Doctoral dissertation, Budapesti Corvinus Egyetem).

12. Gelei, A., \& Nagy, J. (2004). Partnerkapcsolatok értéke a hazai autóipari ellátási láncban Fókuszban a beszállító vállalatok (The value of the partner relationships in the Hungarian automotive supply chain), Múhelytanulmány, BKÁE.

13. Hájek, O., Grebenicek, P., \& Novosák, J. (2011). Regional Innovation Strategies in the Czech Republic. Journal of Competitiveness. 3(2). 11-19.

14. Helo, P. (2004). Managing agility and productivity in the electronics industry, Industrial Management \& Data Systems, 104(7), 567-577. doi.org/10.1108/02635570410550232

15. Kallunki, J.-P., Laitinen, E. K., \& Silvola, H. (2011). Impact of enterprise resource planning systems on management control systems and firm performance. International Journal of Accounting Information Systems, 12(1), 20-39. doi:10.1016/j.accinf.2010.02.001 
16. Karimi, J., Somers, T. M., \& Bhattacherjee, A. (2007). The impact of ERP implementation on business process outcomes: A factor-based study. Journal of Management Information Systems, 24(1), 101-134. doi:10.2753/MIS0742-1222240103

17. Kral, P., Tripes, S., Pirozek, P., \& Pudil, P. (2012). Corporate Governance Against Recommendations: The Cases of the Strong Executive and the Strong Ownership. Journal of Competitiveness. 4(3), 46-57. doi: 10.7441/joc.2012.03.04.

18. KSH (2015): A járműipar helyzete és szerepe a Nyugat-Dunántúlon [The status and role of automotive industry in Western Transdanubia] http://www.ksh.hu/docs/hun/xftp/ idoszaki/regiok/gyorjarmuipar.pdf

19. Lee, D., Lee, S. M., Olson, D. L., \& Chung, S. H. (2010). The effect of organizational support on ERP implementation. Industrial Management and Data Systems, 110(2), 269-283. doi:10.1108/02635571011020340

20. Leem, C. S., \& Kim, I. (2004). An integrated evaluation system based on the continuous improvement model of IS performance. Industrial Management \& Data Systems. 104(2), 115128. doi.org/10.1108/02635570410522080

21. Lepsényi, I; A magyarországi gépjármű és beszállító ipar aktuális helyzete (The actual situation of vehicle and supplier industries in Hungary), „A magyarországi gépjármúipar - Aktuális jogi és gazdasági kérdések” c. konferencia, 2010; Budapest.

22. Malhotra, N. K. (2009). Marketing Research: An Applied Orientation (6th Edition). Pearson

23. Nwankpa, J. \& Y. Roumani (2014). Understanding the link between organizational learning capacity and ERP usage: An empirical explanation, Computers in Human Behavior, 33, 224 234. doi:10.1016/j.chb.2014.01.030

24. Nwankpa, J. K. (2015). ERP system usage and benefit: A model of antecedents and outcomes. Computers in Human Behavior, 45, 335-344. doi:10.1016/j.chb.2014.12.019

25. Peppard, J., \& Ward, J. (2004). Beyond strategic information systems: towards an IS capability, Journal of Strategic Information Systems, 13(2), 167-194. doi:10.1016/ j.jsis.2004.02.002

26. Porter, M. E., \& Millar, V. E. (1985). How information gives you competitive advantage. Harvard Business Review. 64 (4), 149-160.

27. Rechnitzer, J., \& Smaho, M. (2012). Economic Effects of the Vehicle and Automotive Industry in the Regions of Central and Eastern Europe and Hungary. In: Vehicle Industry and Competitiveness of Regions in Central and Eastern Europe, 7-32. Széchenyi István University, UniversitasGyőr. Nonprofit Ltd.

28. Schwarz, A., \& Chin, W. (2007). Looking forward: Toward an understanding of the nature and definition of IT acceptance. Journal of the Association for Information Systems. 8 (4), 230-243. http://aisel.aisnet.org/jais/vol8/iss4/13

29. Seddon, P. B., Calvert, C., \& Yang, S. (2010). A multi-project model of key factors affecting organizational benefits from enterprise systems. MIS Quarterly. 34(2), 305-328.

30. Shang, S. \& Seddon, P. (2002). Assessing and managing the benefits of enterprise systems: the business manager's perspective. Information Systems Journal, 12(4), 271-299. doi: 10.1046/ j.1365-2575.2002.00132.x 
31. Sun, Y., Bhattacherjee, A., \& Ma, Q. (2009). Extending technology usage to work settings: the role of perceived work compatibility in ERP implementation. Information and Management, 46(6), 351-356. doi:10.1016/j.im.2009.06.003

32. Swan, J., Newell, S., \& Robertson, M. (1999). The illusion of 'best practice' in information systems for operations management. European Journal of Information Systems, 8 (4). 284-293. http://dx.doi.org/10.1057/palgrave.ejis.3000336

33. Teo, T. S. H., \& Bhattacherjee, A. (2014). Knowledge transfer and utilization in IT outsourcing partnerships: A preliminary model of antecedents and outcomes. Information \& Management. 51(2), 177-186. doi:10.1016/j.im.2013.12.001

34. Tsai, K. H., \& Hsu, T. T. (2014). Cross-functional collaboration, competitive intensity, knowledge integration mechanisms, and new product performance: A mediated moderation model. Industrial Marketing Management, 43(2), 293-303. http://dx.doi.org/10.1016/j.indmarm an.2013.08.012

35. Venkatesh, V., \& Bala, H. (2008). Technology acceptance model 3 and a research agenda on interventions. Decision Sciences, 39(2), 273-315. doi: 10.1111/j.1540-5915.2008.00192.x

36. Verdú, A. J., \& Gómez-Gras, J. (2009). Measuring the organizational responsiveness through managerial flexibility. Journal of Organizational Change Management, 22 (6), 668-690. doi:10.1108/09534810910997069

37. Wallace, Th. F., \& Kremzar, M. H. (2006). ERP - Vállalatirányítási rendszerek (ERP: Making It Happen: The Implementer's Guide to Success with Enterprise Resource Planning), HVG Kiadó Rt., Budapest

38. Weill, P., \& Olson, M. H. (1989). An assessment of the contingency theory of management information systems. Journal of Management Information Systems, 6(1), 59-85. doi:10.1080/07421 222.1989.11517849

39. Wilson, D., Avison, D., Jones, J., \& Powell Ph. (2004). Using and validating the strategic alignment model, Journal of Strategic Information Systems, 13(3), 223-246. doi:10.1016/ j.jsis.2004.08.002

40. Zajac, E. J., Kraatz, M. S., \& Bresser, R. K. F. (2000). Modeling the dynamics of strategic fit: a normative approach to strategic change. Strategic Management Journal. 21(4), 429-453. doi: 10.1002/(SICI)1097-0266(200004)21:4<429:AID-SMJ81>3.0.CO;2-\#

\section{Contact information}

Ida Ercsey PhD, Associate Professor

Széchenyi István University

Kautz. Gyula Economics Faculty

9026. Györ, Egyetem tér 1. Hungary

E-mail:ercsey@sze.bu 